\title{
月面長期滞在方法に関する一提案 （月面模擬環境装置の構築と有効性の実験的検証）
}

野津 亮太 ${ }^{* 1}$, 長野 方星 ${ }^{* 2}$ ，小川 博之 ${ }^{* 3}$

\section{A proposal of lunar long duration method (Fabrication of lunar environment simulator and experimental validation)}

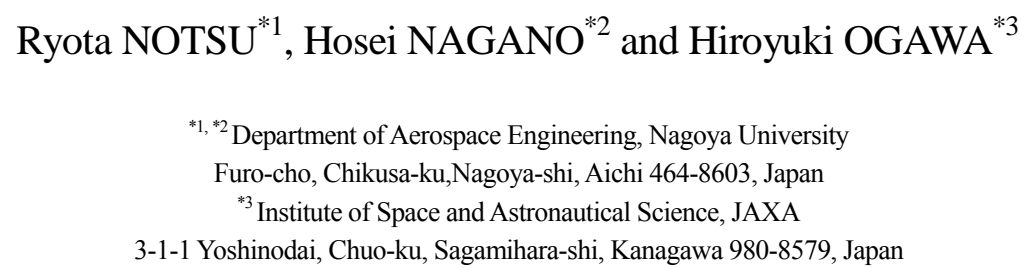

Received 27 January 2014

\begin{abstract}
A lunar long duration method which utilizes a characteristic of a very low thermal conductivity of lunar regolith has been proposed. The principle of this method is to put heater in desired depth of the regolith and heat up the regolith layer during lunar daytime. Because of the very low thermal conductivity of regolith, stored heat in regolith propagates gradually and raises the surface temperature at cold lunar night. By this method, a lunar lander will be kept warm passively during cold lunar night. In this paper, a temporospatially small-scale experimental apparatus which simulate lunar surface environment was fabricated and thermal cycling condition and heater setting position was calculated by comparing lunar environment, and thermophysical properties of the lunar regolith and regolith simulant used in this work. The feasibility of a passive thermal control method with no electrical power during lunar night time was evaluated.
\end{abstract}

Key words : Lunar mission, Lunar regolith, Thermal conductivity, Thermal control

\section{1. 背景および目的}

月は地球から最も近い天体であり，人類は 1969 年のアポロ 11 号で初めて降り立った. アポロ計画以降，月 へのアプローチは軌道上からの観測が主となっていた。しかし近年，月面に軟着陸して探査を行う動きが世界 的に再燃しており，中国では他に先駆け 2013 年 12 月に無人探査機の打ち上げと月面への着陸を成功させた (ZeZhou, et al., 2013). またロシアを中心とするヨーロッパ諸国やインドも名乗りを上げており, 日本でも SELENE-2 計画で 2015 年頃の無人着陸探査を予定している (Kokhanov, et al., 2012, and Tanaka, et al., 2013). 月探 查は地球の起源を探るため, また今後の宇宙開発の足掛かりとして大きな意義を持つ.

月面は公転周期の関係で，昼と夜が地球時間にして 29.53 日周期で訪れる (Langseth, et al., 1973). 加えて，月 の大気は非常に希薄であるため, 昼夜の温度差が非常に大きくなる．特に，夜間は外部エネルギー（太陽光エ ネルギー）の利用が不可能であり，電力リソースが不足するため，熱設計が成立し難い．これまでの月面探査 機の多くは，夜間保温のために原子力電池を搭載しており，その他のケースの多くは越夜を考えていない (Ulamec, et al., 2010). しかし，日本の宇宙開発においては原子力を用いることができないため，長期に渡る探査

\footnotetext{
No.14-00044 [DOI: 10.1299/transjsme.2014tep0199]

${ }^{* 1}$ 名古屋大学大学院 工学研究科（广464-8603 愛知県名古屋市千種区不老町）

*2 正員, 名古屋大学大学院 工学研究科

*3 正員, 宇宙航空研究開発機構 宇宙科学研究所（广252-5210 神奈川県相模原市中央区由野台 3-1-1）

E-mail of corresponding author: nagano@prop2.nuae.nagoya-u.ac.jp
} 
や夜間の探査を行う場合，新たな提案が不可欠となる，そこで本研究は，月面上のレゴリスを利用する新たな パッシブ熱制御手法を提案する.レゴリスは月面に堆積する細かい砂で, 特徵として低熱伝導性・高蓄熱性を 有している．本提案では，表面から一定深さに存在するレゴリスを昼間に加熱することでレゴリス地中に蓄熱 し，熱拡散の時間応答の遅れを利用して，夜間にレゴリス表面に伝わった熱を利用して探査機を温めるという 新しい手法である。レゴリスを加熱・変態させ，越夜の熱源に用いる方法は近年海外でも研究されつつある (Balasubramaniam, et al., 2010). その中において，本研究で提案する手法は，レゴリスとヒータを組み合わせた熱 制御方法であり, 他の提案よりも簡単な機構による受動的な熱制御が可能であるため, 月へ持ち込む装置を少 なく抑えられる利点がある. 本論文では, 新しい越夜方法の有効性を検証するための第一段階として, 月表面 およびレゴリス層内の熱環境を, 時間および空間スケールを縮小して模擬できる装置を新たに構築した. また， 実際の月面周期加熱環境を小型月面模擬装置で等価的に模擬するため，月面熱環境条件，レゴリスの熱物性， 実験用レゴリスシミュラントの熱物性，および実験装置スケールの関係から，周期加熱条件ならびにヒータ設 置深さを求めた。 さらに, 構築した小型月面模擬装置と決定された周期加熱条件を用いて, 本提案の受動型熱 制御手法の妥当性の検証を行ったので報告する.

\section{2. 月面環境および提案手法}

\section{$2 \cdot 1$ 月面環境}

月では大気による対流の影響をほぼ無視出来るため, 温度は太陽光熱入力, 宇宙空間とのふく射熱交換, 月 面深部に存在する放射性同位体の崩壊熱による熱入力のバランスにより決定される. 昼間は太陽光直射（1323 $\left.\sim 1414 \mathrm{~W} / \mathrm{m}^{2}\right)$ により月表面の温度は上昇する. アルベドが 0.11 程度と地球に比べ小さいため, 太陽光による熱 入力は地球よりも大きい，一方夜間は，宇宙空間とのふく射熱交換により月表面温度は急激に低下する．これ らの理由から, 月表面の昼夜の温度差は大きくなる。一方で月表面は先述したレゴリスにより覆われており， その熱伝導率の低さから，レゴリス内部では深さ方向に従い温度変化幅（温度振幅）が急激に減衰する.月表 面から深さ $1 \mathrm{~m}$ 付近まで数点の温度履歴は Apollo15, Apollo17 計画における熱流束観測で測定されている. 図 1 に月表面のおよび深さ $670 \mathrm{~mm}$ 付近の温度履歴を示寸(Langseth, et al., 1973). これよりレゴリス表面では昼と夜で $-190 \sim+100^{\circ} \mathrm{C}$, つまり約 $300^{\circ} \mathrm{C}$ の大な温度変化が存在する. 一方, レゴリス表面から梁さ $67 \mathrm{~cm}$ の温度測定位 置では，一定の温度環境が得られていることが見て取れる.

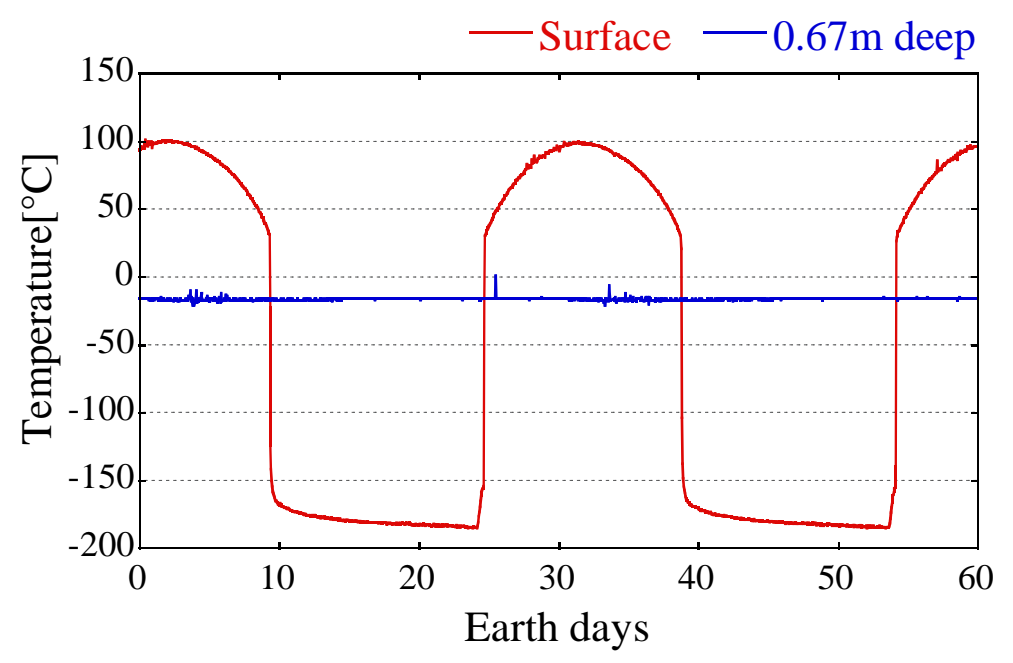

Fig. 1 Lunar Surface and Internal Temperature Histories

\section{$2 \cdot 2$ 長期滞在方法の提案}

本研究では月に大量に存在するレゴリスの低熱伝導性, 蓄熱性に着目した新しい熱制御方法を提案する. 具 体的なイメージを図 2 に示寸. 昼間は, 通常の宇宙機の熱設計と同様に, 衛星内部の機器の放熱はラジエータ より行われる。 またその間, 太陽電池で発電した余剩電力をレゴリス層内に埋蔵したヒータに供給し，レゴリ 
ス層内部を高温に加熱して蓄熱する．レゴリス内部の温度は高温になるが，ヒータを設置する深さを変化させ ることで，その熱が表面に伝わる時間を設定できるため，昼間に加熱の影響は表れない，一方，夜間は熱入力 および電力供給が断たれ低温となるが，昼間にヒータを中心に高温となったレゴリスの熱が地表面に伝わるこ とで，地表面が温められる．上記のレゴリス層内蓄熱方式により，夜間に電力を必要とすることなくパッシブ な熱制御が可能であると考えられる．さらに，放熱面は可逆展開型の自律型吸放熱デバイス (Nagano, et al., 2011）を用い，昼間は放熱フィンを展開，夜間は放熱フィンを収納して放熱面を覆い隠す構造とすることで， 更なる放熱・保温効果が期待できると考える.

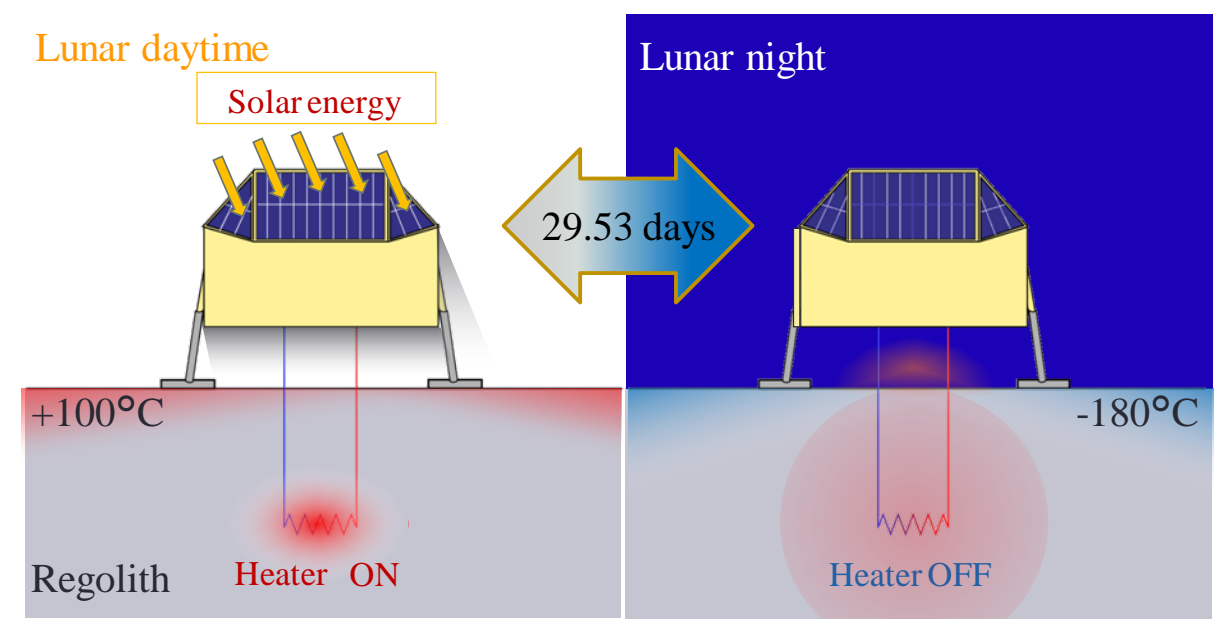

(a) Lunar Daytime

(b) Lunar Night

Fig. 2 Schematic View of Proposed Method

\section{3. 月面環境模擬装置の構築}

本提案の有効性を確認するためには，月面環境を模擬した装置が必要となる．しかしながら，実際の月面環 境および昼夜の加熱・冷却条件を完全に再現することは難しい，また，仮に実現できたとしても，試験にも膨 大な時間と労力を要する. そこで本研究では, 時間および空間スケールを縮小した月面環境模擬装置を構築し, 最終的にはその実験結果を月面実スケールで議論することで本提案の有效性を検証する.

\section{$3 \cdot 1$ 月面模擬装置概要}

図 3 に新たに構築した月面模擬装置の概略図を示す. 装置は真空チャンバー，シュラウド，レゴリスシミュ ラント, 真空排気系, 冷却系, 電源, 計測・制御系より構成される. 真空チャンバーはSUS 製で, サイズは内 径 $\phi 497 \mathrm{~mm} \times$ 長さ $1032 \mathrm{~mm}$ の縦置円筒型である. チャンバー内上部にはシュラウド, 下部にはレゴリスシミュ ラントが設置される。 レゴリスシミュラントには豊浦標準砂を選定し, チャンバー底面のフランジに乗せ設置 する. 図 4 にシミュラント容器断面と温度測定点を示寸. 容器サイズは内径 $\phi 370 \mathrm{~mm}$, 高さ $450 \mathrm{~mm}$ で, 材質 には伝導伝熱を抑制するために, 熱伝導率の低いポリエチレン（Polyethylene, PE）を選定した．また，容器周 囲はアルミニウム蒸着ポリエステル 10 層とポリエステルネットより構成される多層膜断熱材 (Multilayer insulation, MLI）で覆われ，外界と断熱される. さらに，容器はデルリン材を介して支持台の上に置くことで伝 熱交換を抑制している.

シュラウドは内径 $\phi 404 \mathrm{~mm}$, 高さ $419 \mathrm{~mm}$ で, 銅製パイプ（外径 $\phi 8 \mathrm{~mm}$, 内径 $\phi 6 \mathrm{~mm}$ ) を螺旋状に巻いて溶 接されたシュラウド側面部と, 円盤に銅製パイプを蛇行させ溶接したシュラウド上部から構成される. 両部位 共に, パイプ内部に液体窒素を流入することで泠却, さらに表面に均熱性の高いアルミテープにより貼り付け られたテフロン被覆コンスタンタン製ヒータにより加熱を行い, 液体窒素沸点 $\left(-196^{\circ} \mathrm{C}\right)$ から $+100^{\circ} \mathrm{C}$ まて温度 を変化させることが可能である. シュラウド内面には黒色塗料 (ニッペノバ・アストロブラック 500) が塗布さ れており，シミュラント表面との放射交換により温度制御を行う。また，シュラウド外部は MLIで覆われ，外 界と断熱される。 
シュラウドおよびシミュラントの温度計測は, 線径 $200 \mu \mathrm{m}$ の $\mathrm{T}$ 型熱電対 40 対で行う．シュラウドの温度分 布測定は熱電対 7 対により行われ， 7 点の平均值が所望の温度プロファイルを取るように PID 制御される.シ ミュラント内部および容器の温度は熱電対 33 対により行われる. 温度測定点は図 4 内の黒点で示され, 容器中 心線上は各深さ計 20 点に熱電対を固定し測定を行う。測定間隔は表面から深さ30mm までを最も細かく5 $5 \mathrm{~mm}$ とし，深さが増すにつれて $10 \mathrm{~mm}, 20 \mathrm{~mm}, 30 \mathrm{~mm}$ 及び $100 \mathrm{~mm}$ 間隔で深さ $300 \mathrm{~mm}$ まで測定を行う。さらに，半 径方向の温度分布を測定するために半径 $60 \mathrm{~mm}, 125 \mathrm{~mm}$, 深さ $50 \mathrm{~mm}, 100 \mathrm{~mm}, 200 \mathrm{~mm}, 300 \mathrm{~mm}$ の各点および

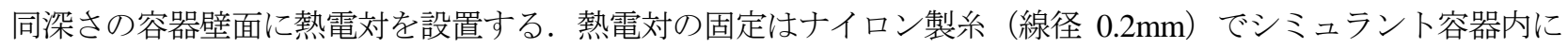
吊り下げる形で固定し, その後容器内にシミュラントを充填する. 供試体設置後, 油回転ポンプおよび油拡散 ポンプを用いて排気を行い $10^{-4} \mathrm{~Pa}$ オーダまで圧力を下げた後実験を開始する.シミュラントの初期温度は約 $20{ }^{\circ} \mathrm{C}$ で一様であった。

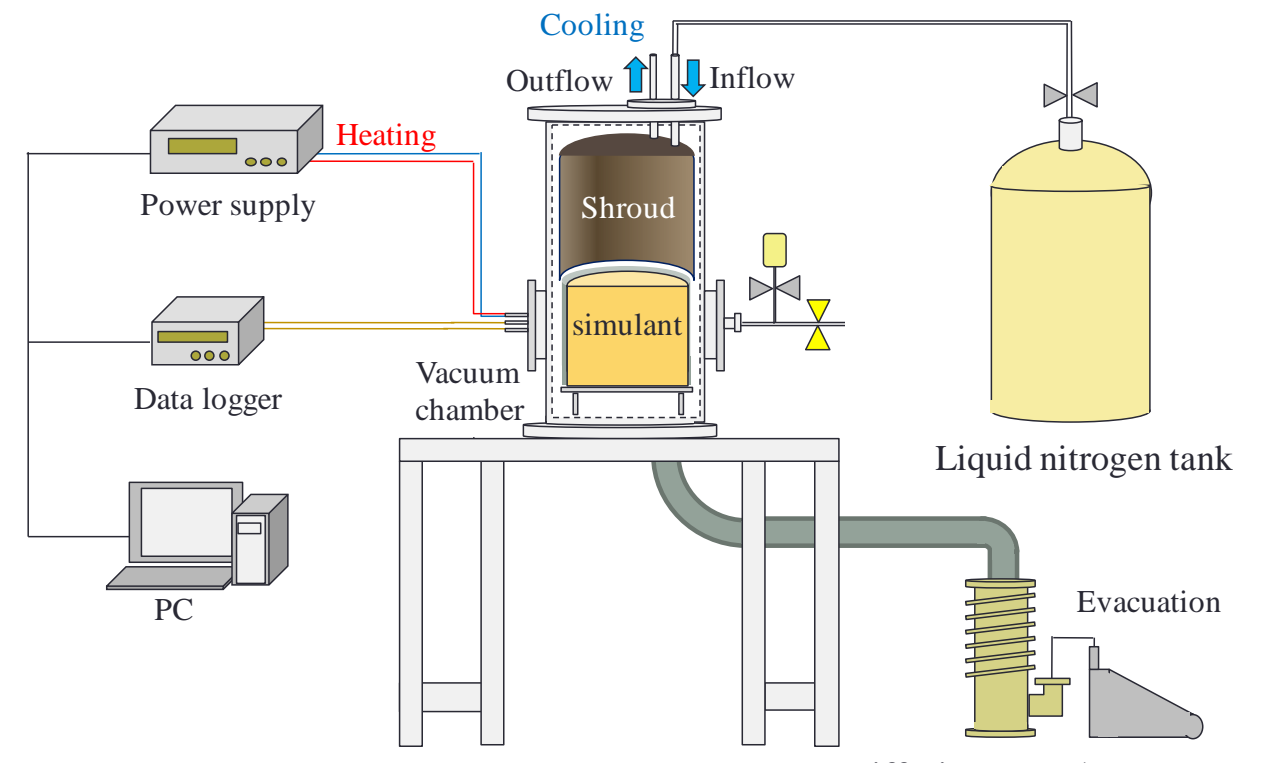

Diffusion pump/ Rotary pump

Fig. 3 Schematic View of Experimental Apparatus

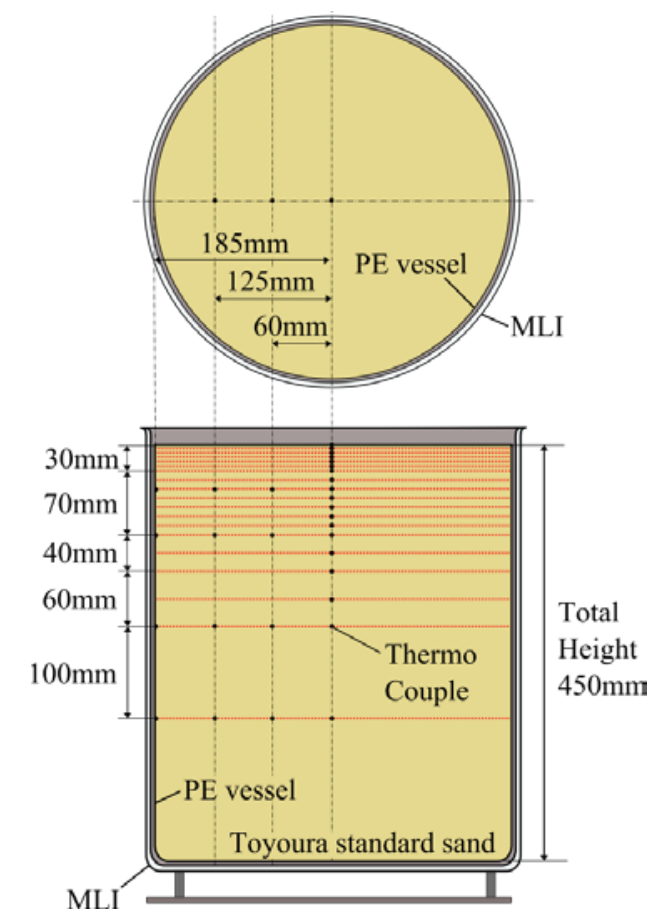

Fig. 4 Simulant Case and Temperature Measurement Points 


\section{$3 \cdot 2$ 設置ヒータ}

本提案を実証するため, 図5に示すように豊浦標準砂内に4本のカードリッジヒータ (外径 $\phi 5 \mathrm{~mm}$, 長さ $50 \mathrm{~mm})$ を埋めた．本実験では表面からの加熱位置を規定するため，図 5 (a)に示すようにシミュラント表面と平行に十 字に挿入した。実際の挿入の様子を図 5 (b)に示す. ヒータの温度測定には線径 $50 \mu \mathrm{m}$ の $\mathrm{K}$ 型熱電対を用いた. 電力供給線には, 線径 $0.2 \mathrm{~mm}$ の銅線を用い, 熱リークを抑えるために約 $1 \mathrm{~m}$ をヒータと同様の深さに設置した.

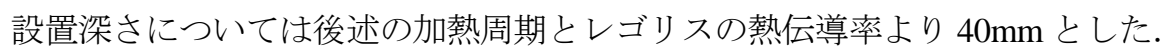

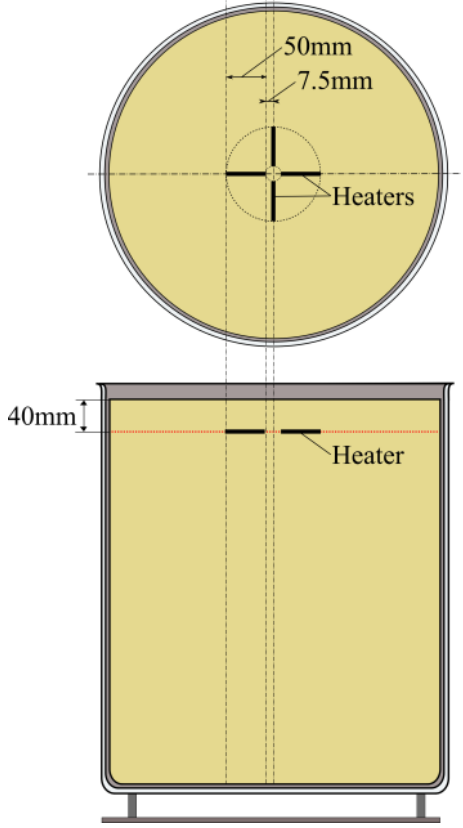

(a) Heaters Setting Position

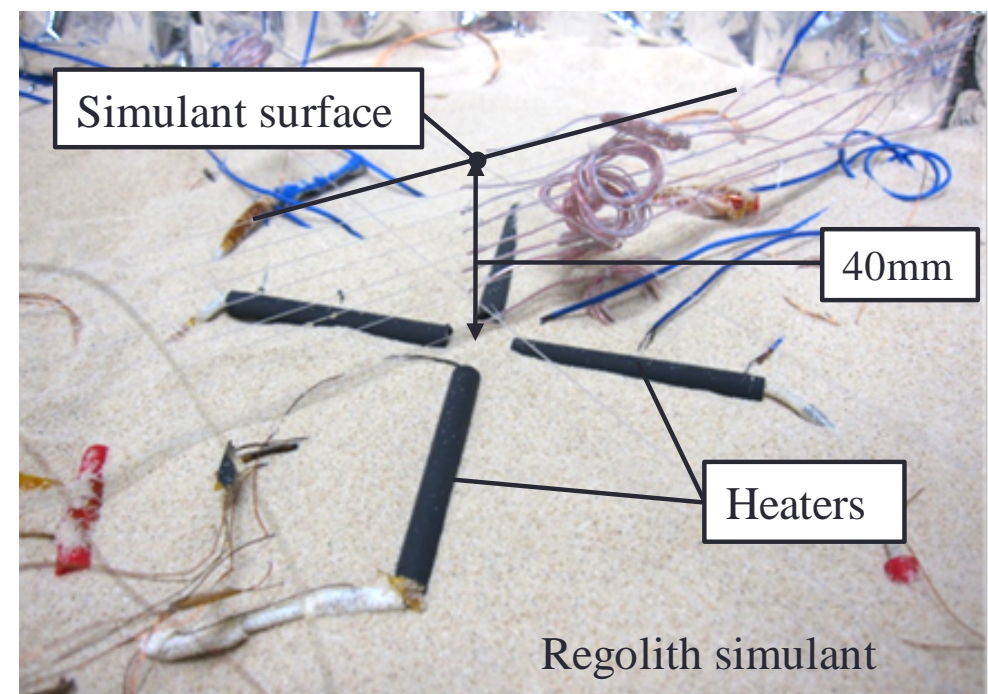

(b) Photo of Heaters Setting

Fig. 5 Overview and Photo of Heaters Setting

\section{4. 加熱周期条件とヒータ設置深さの決定}

月面の温度変化周期は月の一日と同じく 29.53 地球日（約 709 時間）であり，上述した様に月面では大きな温 度変化が生じる. 一方，レゴリス層内の深さ $670 \mathrm{~mm}$ において一定温度領域が存在することが知られている. こ れは月表面の温度変化周期から考えると比較的浅い位置であると言えるが，レゴリスの熱伝導率が月表層付近 で約 $0.001 \mathrm{~W} /(\mathrm{m} ・ \mathrm{~K})$, 内部で約 $0.01 \sim 0.1 \mathrm{~W} /(\mathrm{m} ・ \mathrm{~K})$ と非常に小さいことから説明できる (Heiken, et al., 1991). た だし APPOLO の計測では測定用プローブ挿入の影響, プローブからの熱放射の影響を排除出来ていないことか ら (Langseth, et al., 1973), 実際は670mm よりも浅い位置で一定温度層が成立していると考えられる.

レゴリス層内において太陽光による月表層への加熱信号は減衰し，ある深さにおいてほぼ信号が得られなく なる. その深さは表層の温度振幅と以下に示す熱拡散長 $L$ によって見積もることが出来る. 熱拡散長 $L$ は熱源 の温度振幅が1/e となる距離を表しており，式(1)のように表わされる.

$$
L=\sqrt{\frac{\lambda}{\pi \rho C_{P} f}}
$$

ここで $\lambda$ は熱伝導率， $C_{P}$ は定圧比熱， $f$ は加熱周波数で温度変化周期の逆数である. 式(1)と次に示す一次元 熱伝導の方程式から月面および本実験での一定温度成深さとヒータの設置深さについて考察する.

$T_{0}$ の温度振幅を持つ温度振幅源からの位置 $x$ における温度振幅の減衰と位相遅れの関係は以下で表される. 


$$
T_{(x, t)}=T_{0} e^{-\frac{1}{L} x} \sin \left(\omega t-\frac{1}{L} x\right)
$$

ここで月面の温度振幅は最高温度と最低温度の差の $1 / 2$ とし, 図 1 より約 $150^{\circ} \mathrm{C}$ である. 本考察ではレゴリ 久層内の温度振幅が $0.5^{\circ} \mathrm{C}$ 以下となる深さ $x$ を一定温度層の成立位置と考える. 深さ $x$ は式(2)の減衰項より

$$
150 \times e^{-\frac{1}{L} x}=0.5
$$

と表せる.これより

$$
x \approx L_{M} \times 6
$$

を得る.ここで $L_{M}$ は月面レゴリスの熱拡散長を表す. 表 1 の值を用い月面での一定温度層成立位置は約 $350 \mathrm{~mm}$ と見積もられる.ただし本予測では深さ $670 \mathrm{~mm}$ より浅い位置で $250 \mathrm{~K}$ の場合のレゴリス熱伝導率予測值(Notsu, et al., 2013)から，レゴリス熱伝導率を $0.005 \mathrm{~W} /(\mathrm{m} ・ \mathrm{~K})$ と想定した.

同様の考察から本研究で用いる実験装置での加熱冷却周期条件を決定する．本実験では月面の温度環境を模 擬するためシュラウド温度を $-190^{\circ} \mathrm{C} \sim+100^{\circ} \mathrm{C}$ で変化させる. この時シミュラント表面に同様の温度変化を仮定 すると，温度振幅は月面と同じく約 $150^{\circ} \mathrm{C}$ である. 式(3)と同様の計算から一定温度成立深さは

$$
x \approx L_{E} \times 6
$$

となる.ここで $L_{E}$ は実験に用いるレゴリスシミュラントの熱拡散長である.つまり実際の月面と本実験装置の 一定温度層成立深さ $D$ の間には以下のような関係がある。

$$
\frac{D_{M}}{D_{E}}=\frac{L_{M}}{L_{E}}
$$

ここで $D_{M}, D_{E}$ はそれぞれ月面レゴリスの熱拡散率と本実験で使用するシミュラントの熱拡散率を表す．熱 拡散長は伝熱媒体の熱物性と加熱冷却周期によって決まるため, 実験では加熱冷却周期を設定する必要がある. 加熱冷却周期の決定する際考慮すべき点として, 以下の 2 点が挙げられる. 1 つは一定温度層をシミュラントの 中心付近に成立させること, もう 1 つは容器中心付近で深さ方向に一次元的な温度変化領域を成立させること である．つまり加熱冷却周期を長くすると，より深い位置に一定温度層が成立し実際の月面温度環境に近くな るが，一方でシミュラントよりも伝熱特性の良いポリエチレン容器の温度上昇による影響が容器中心付近の一 次元性に影響を及ぼす可能性がある. 今回はこれらの制約条件から，一定温度層を深さ約 $80 \mathrm{~mm}$ に成立させる 設計とした。このとき，

$$
L_{E} \approx 80 / 6 \approx 13
$$

となり，この熱拡散長を満たす周期 $f$ から加熱冷却周期を 48 時間と決定した. また，この時シミュラント容器 の温度変化がシミュラント温度変化に与える影響は最高でも容器側面より $80 \mathrm{~mm}$ までに抑えることが出来る.

次に熱制御用のヒータ設置深さについて述べる．ヒータは 2 節で述べたように月面昼間の時間带のみ加熱す る. そして高温になったレゴリスの熱が極低温となる夜間，月表面に伝搬するよう適切な深さに設置する．こ の深さは式(2)の位相遅れを表す $\sin$ 項から決定する. 月の 1 日を 1 周期とすると, 昼と夜の位相差は半周期で あるため, 以下の式で求められる深さ $x$ が求める深さと考える.

$$
\frac{1}{L} x=\pi
$$

これより, 月面ではヒータを深さ約 $180 \mathrm{~mm}$ に設置すれば昼間のヒータ加熱の効果を夜間月表面に得ることが 出来ると考えられる．ただし，これはレゴリスが理想的な条件下にあるという仮定の基の考察であり，実際は 探查機着陸時やヒータ挿入時におけるレゴリスの飛散や圧縮の影響を考慮する必要がある。一方, 実験におい ては，同様の見積もりから深さ約 $40 \mathrm{~mm}$ にヒータを設置する．これにより夜間を模擬した時間にヒータ加熱の 効果がシミュラント表面に現れる. 
実際の月面環境と，実験条件の対応を明らかにするため，式(2)から得られる温度振幅とレゴリス深さの関係 を図 6 に示す. 図 6 (a)が月面環境下, 図 6 (b)が実験環境下での温度伝搬を示している. 表面最高温度を $100^{\circ} \mathrm{C}$,

一定温度層は月面環境で- $20^{\circ} \mathrm{C}$ ，実験環境下で $20^{\circ} \mathrm{C} と し ， 1.5$ 周期分が描かれている.

月面環境下において熱拡散長 $L_{M}$ は約 $58 \mathrm{~mm}$ と予測され，この深さで表面温度振幅が $1 / e$ に減衰する. 次に $L_{M} \times \pi($ 約 $180 \mathrm{~mm})$ で温度が逆位相となることから，この位置にヒータを設置することを考える. そして $L_{M} \times 6$ (約 $350 \mathrm{~mm}$ )付近で一定温度領域が成立する. 実験条件下においてはレゴリス及び豊浦標準砂の熱拡散長の差か らそれぞれ月面環境下よりも浅い位置となる. 表 1 に月面環境, レゴリス熱物性, 本実験で用いたレゴリスシ ユミラント (豊浦標準砂) の熱物性, および実験条件の対比を示す(Notsu, et al., 2013, and Tarnawski, et al., 2009).

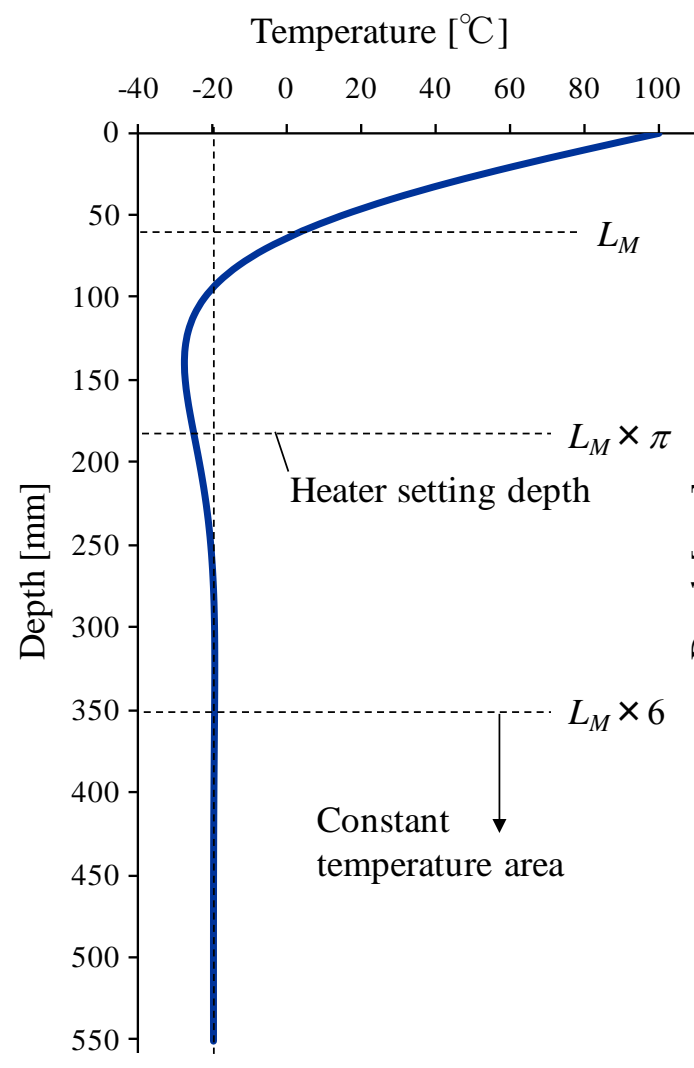

(a) Lunar Environment

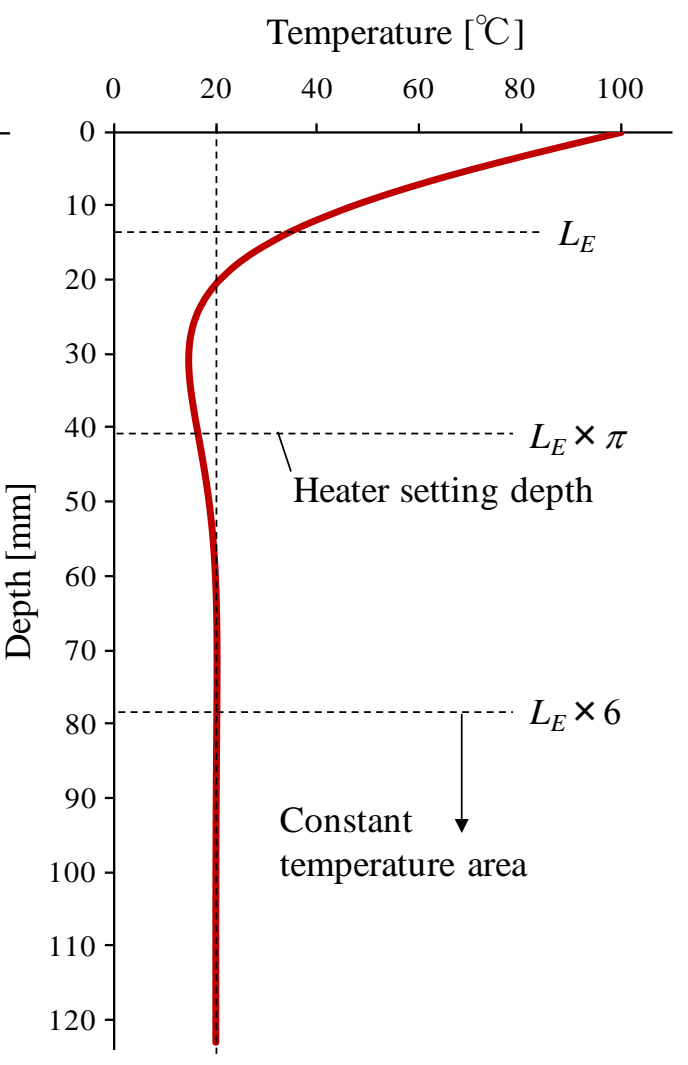

(b) Experimental Condition

Fig.6 Relations Between Thermal Diffusion Length and Temperature Distribution

Table 1 Comparison of Lunar Surface and Experimental Condition

\begin{tabular}{|r|c|c|}
\hline \hline & $\begin{array}{c}\text { Lunar Surface } \\
\text { (Regolith) }\end{array}$ & $\begin{array}{c}\text { Experimental Apparatus } \\
\text { (Toyoura Standard Sand) }\end{array}$ \\
\hline Density $\left(\mathrm{g} / \mathrm{cm}^{3}\right)$ & 1.7 & 2.63 \\
\hline Thermal Conductivity $(\mathrm{W} /(\mathrm{m} \cdot \mathrm{K}))$ & 0.005 & 0.015 \\
\hline Specific Heat Capacity $(\mathrm{J} / \mathrm{kgK})$ & 700 & 4842 \\
\hline Heating Period $(\mathrm{hr})$ & 709 & 13 \\
\hline Thermal Diffusion Length $(\mathrm{mm})$ & 58 & 80 \\
\hline Constant Temperature Depth(mm) & 350 & 40 \\
\hline Heater Installation Depth $(\mathrm{mm})$ & 170 & \\
\hline
\end{tabular}




\section{5. 実験結果}

本試験では，まずヒータを用いずにシュラウドの周期的な温度変化に対して，レゴリスシミュラント表面お よび内部の温度応答が設計通りになることを確認する. 次に, 提案の方法でヒータをシュラウド内部に埋め, ヒータ加熱の効果を調べる.

\section{$5 \cdot 1$ ヒータ無し条件}

図 7(a)に容器中心の各深さ（表面 $0 \mathrm{~mm}$ 〜深さ $30 \mathrm{~mm}$ ) およびシュラウドの温度履歴を, 図 7(b)に深さ $50 \mathrm{~mm}$ ～120mm の温度履歴を示す. シュラウド温度は $-190^{\circ} \mathrm{C} \sim+100^{\circ} \mathrm{C}$ 範囲で変化させた, その結果, シミュラント の表面温度は- $110^{\circ} \mathrm{C} \sim+96^{\circ} \mathrm{C}$ の範囲で変化した. その温度変化の振幅は, 深さがますにつれ減衰し, 深さ $80 \mathrm{~mm}$ 以降ではほとんど温度変化がないことが見て取れる.これより, 加熱周期 48 時間において $80 \mathrm{~mm}$ 以下で等温環 境が得られ，本試験装置および温度変化条件が適正であることが示された。
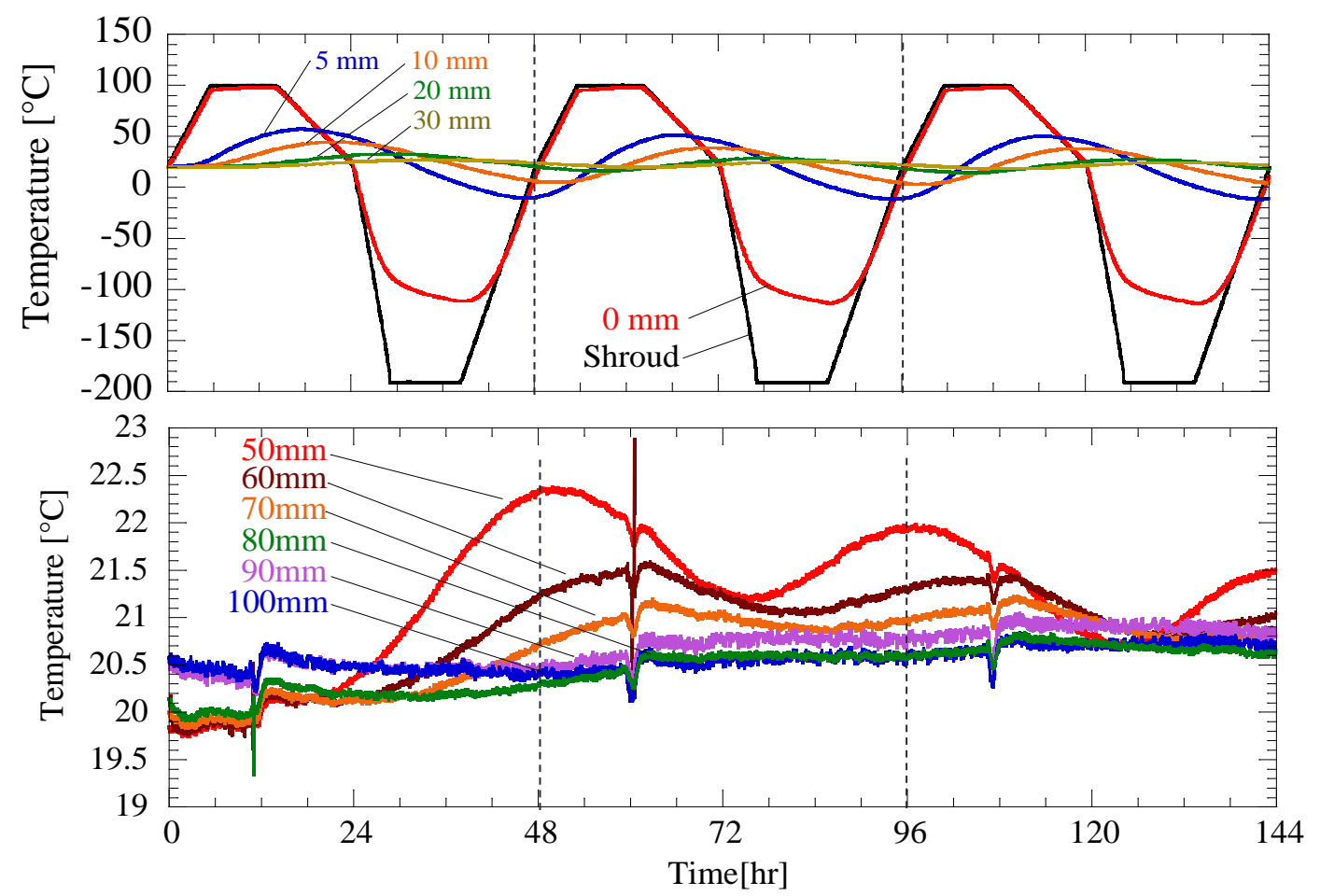

Fig. 7 Temperature Profiles in Regolith Simulant (a)Surface $\sim 30 \mathrm{~mm}, \quad$ (b) $50 \sim 100 \mathrm{~mm}$

次に, 3 次元の温度分布を確認するため. 砂入れ容器の深さ $50 \mathrm{~mm}, 100 \mathrm{~mm}, 200 \mathrm{~mm}$ および $300 \mathrm{~mm}$ の半径方 向温度履歴を図 8 (a)〜(d)に示す. シュラウドの温度変化および表面からの伝熱により PE 容器は温度変化をし ていることが確認できる．一方で，中心から $0 \mathrm{~mm} ， 60 \mathrm{~mm} ， 125 \mathrm{~mm}$ の間の温度を比較すると，位相差は存在し ていないため, PE 容器からの熱流入はなく, 一次元的な温度変化が実現できている. ただし, 深さ $300 \mathrm{~mm}$ 付 近では，PE 容器中心から半径 $125 \mathrm{~mm}$ の温度は上昇している．これは，本実験で意図していないより低周波な 外界の温度変化によるものと考えられる。 この結果より, レゴリス表面からの一次元温度分布は, およそ直径 $125 \mathrm{~mm}$ ，深さ $200 \mathrm{~mm}$ の範囲で確保できていると考えられる. 


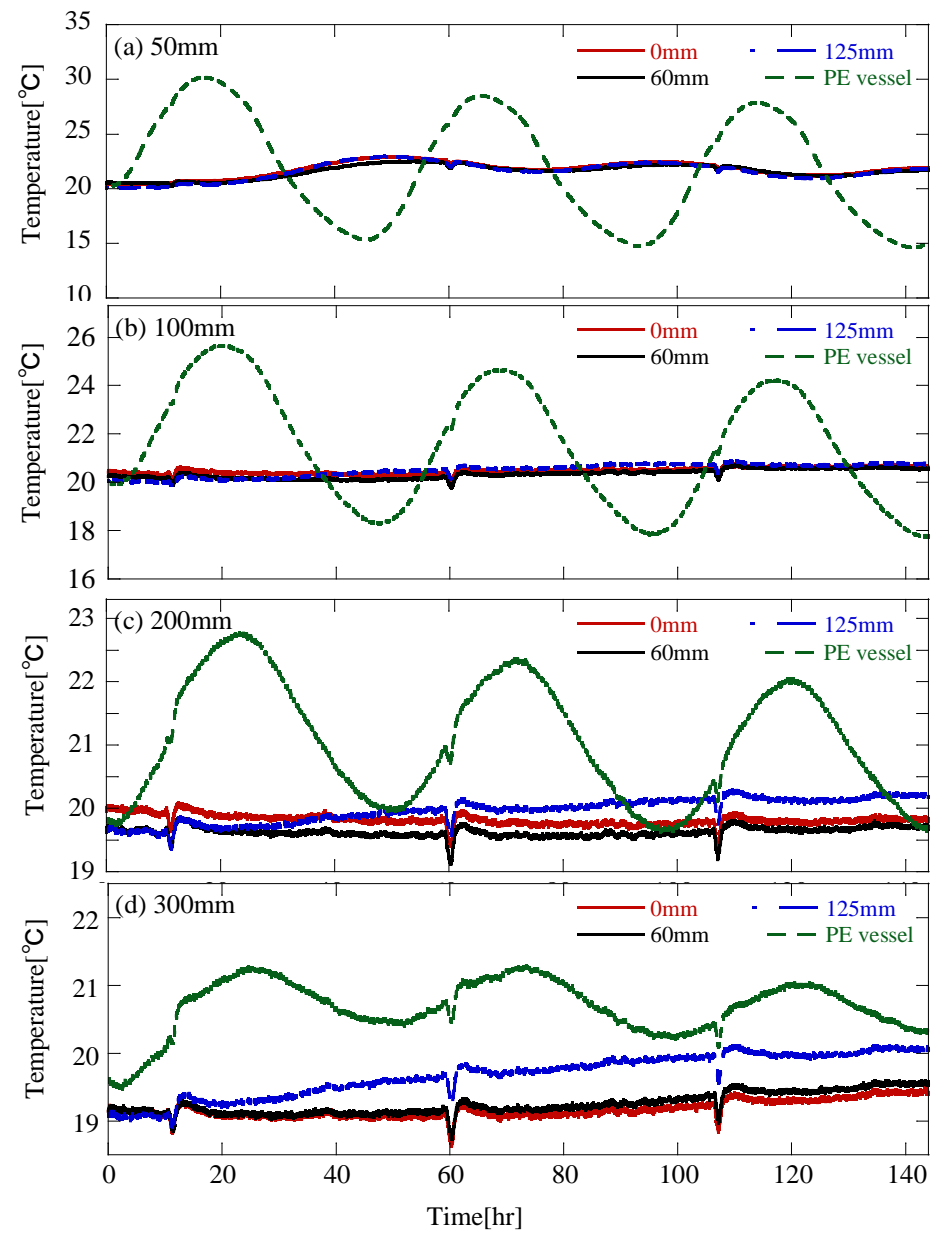

Fig. 8 Temperature Profiles in Radial Direction

(a)50mm depth, (b)100mm depth, (c)200mm depth, (d)300mm depth

\section{$5 \cdot 2$ ヒータ有り条件}

次にヒータを挿入し, 本提案の有効性を確認寸るための試験を行った. 本試験では, 基礎試験と同様に 48 時 間周期の温度変化を与える. また前提として, 砂表面温度のピークがヒータ温度のピークから半周期遅れて現 れる深さを求めて, 模擬試験を行う。つまり，1周期（48 時間）の試験の場合, 試験開始から 36 時間後に, 砂 表面温度に極大值が現れる位置を求める. この深さは, 上述の通り本試験では 40mm とした. 試験は図 9 に示 すような太陽光発電プロファイルを模した電力を供給する.

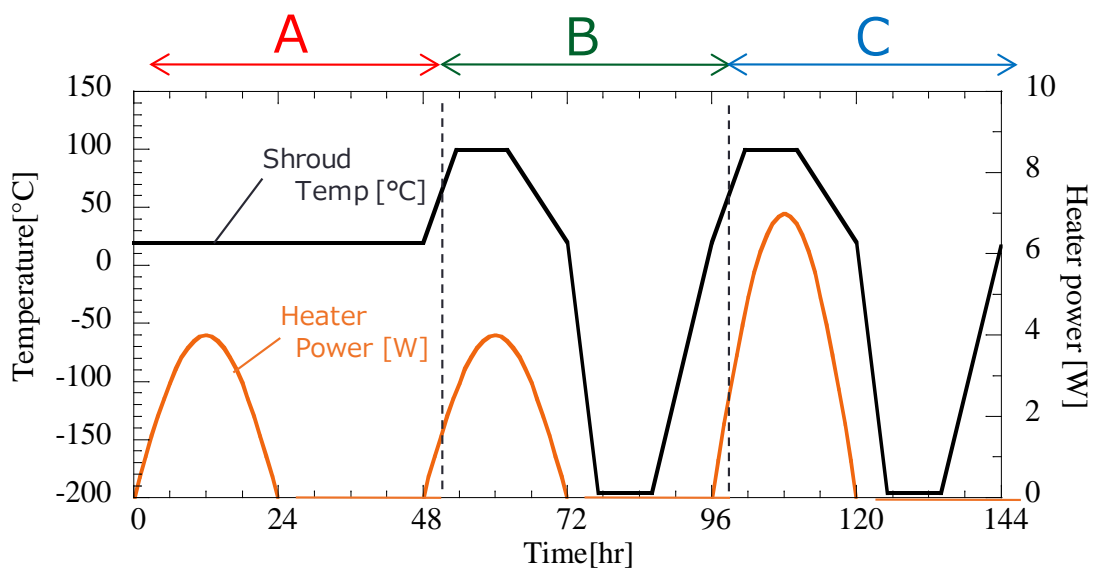

Fig. 9 Input Heater Power and Shroud Temperature History 
供給電力のピークは, 太陽光が南中する各周期の 12 時間後に現れるように設定する. 供給電力は, 最大值 $4 \mathrm{~W}$ および $7 \mathrm{~W}$ でそれぞれ試験を行う。供給電力は, 月面環境では最大 $0.22 \mathrm{~W} / \mathrm{cm}^{2}$ の熱入力でヒータに接触してい るレゴリスが融点付近まで上昇すると見積もられることから, 本実験ではヒータの表面積と熱流束から最大入 力值を $7 \mathrm{~W}$ としている. シュラウド温度を変化させずに電力を供給し, 1 周期分の試験を行い, 砂表面温度が狙 いとする変化を起こすかを確認する（区間 A). その後, 同様の電力供給を保ちつつ, さらにシュラウド温度を 基礎試験で行った $-190^{\circ} \mathrm{C} \sim+100^{\circ} \mathrm{C}$ 範囲で変化させ， 1 周期分の試験を行う（区間 $\mathrm{B}$ ). 次に, 供給電力をピー クが 7W になるように設定し，シュラウド温度を変化させながら 1 周期分の試験を行う (区間 C)。これらの条 件は連続的に変化させる.

図 10 に区間 A（0hr〜48hr）におけるレゴリスシミュラント表面およびシュラウド温度の試験結果を示す，ヒ 一夕加熱が 0 24hr であるのに対し, 表面温度上昇は約 $12 \mathrm{hr}$ 後に開始され, 狙いである $36 \mathrm{hr}$ に近い 35.4hr にお いてピークを迎えている.この結果より, 設置深さは $40 \mathrm{~mm}$ が適切であることが確認された.

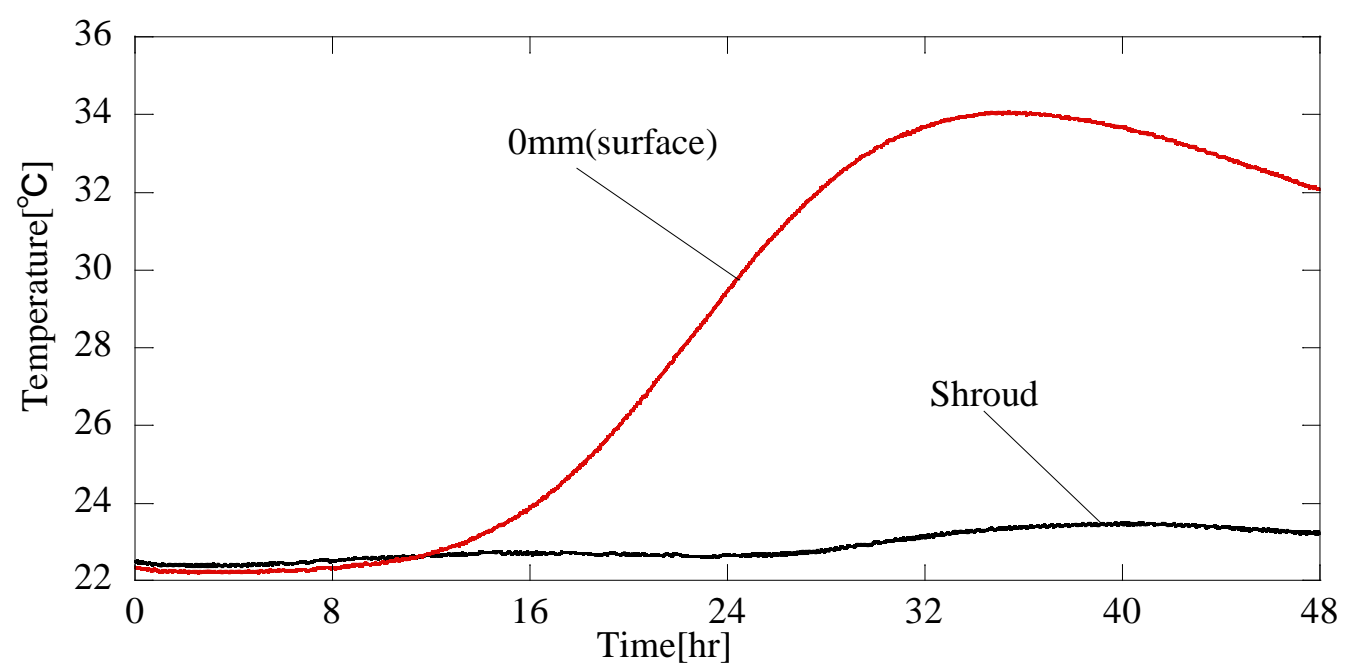

Fig. 10 Input Heater Power and Simulant Surface Temperature (Zone A)

図 11 に試験中のヒータ温度(a)とレゴリスシミュラント内の温度分布(b)を示寸. 区間 B (48hr〜 96hr) では, (a)に示寸ように供給電力のピークが 60hr（2 周期目の 12 時間後）であるのに対し. ヒータ表面温度のピーク は約 $62.5 \mathrm{hr}$ に現れた. また, その温度は約 $370^{\circ} \mathrm{C}$ とった. (b)より, ヒータ位置 $40 \mathrm{~mm}$ から温度減衰と位相 遅れを伴って表面に伝搬していることが見て取れる.しかし, シュラウド表面での温度変化を受けて, 区間 A の時よりも位相遅れが小さくなっていることが分かる. 区間 C（96hr～144hr）の試験結果では，供給電力の ピークは $108 \mathrm{hr}$ であるのに対し, ヒータ表面温度のピークは約 $110.4 \mathrm{hr}$ に現れた. また, その時の温度は約 $530^{\circ} \mathrm{C}$ 程度であった．次に(b)に示寸深さ $5 \mathrm{~mm}$ (表面) 〜深さ $40 \mathrm{~mm}$ までの温度履歴を見ると, 区間 B と同様に. 七 一夕位置 $40 \mathrm{~mm}$ から温度減衰と位相遅れを伴って表面に伝搬していることが見て取れる.

最後に, ヒータ無しの場合と, ヒータ $4 \mathrm{~W}$ 加熱, $7 \mathrm{~W}$ 加熱におけるレゴリス表面温度の変化を重㸚て比較し た結果を図 12 に示す，ヒータ無しの基礎試験結果の最低温度が-113.2 ${ }^{\circ} \mathrm{C}$ あるるのに対し, 最大 $4 \mathrm{~W}$ 加熱時の 最低温度は- $38.5^{\circ} \mathrm{C}$ ま早している. つまり, 最低温度が $\Delta T=74.7^{\circ} \mathrm{C}$ 上昇しており, 昼間のヒータ加熱が夜 間に効果を与えることが確認された．また， $7 \mathrm{~W}$ 加熱時はレゴリス表面温度が- $16.4^{\circ} \mathrm{C}$ ま゙上昇している．ヒー 夕を設置し, 最大 $7 \mathrm{~W}$ の熱量を加えた場合, 設置しない場合に比べて最低温度が $\Delta T=96.8^{\circ} \mathrm{C}$ 上昇している. 以上のことから，月面昼間の太陽光を利用したレゴリス層内蓄熱方式により，夜間に電力を用いることなく レゴリス表面温度を上昇できることが実験的に示され，本提案の有効性が示された。 


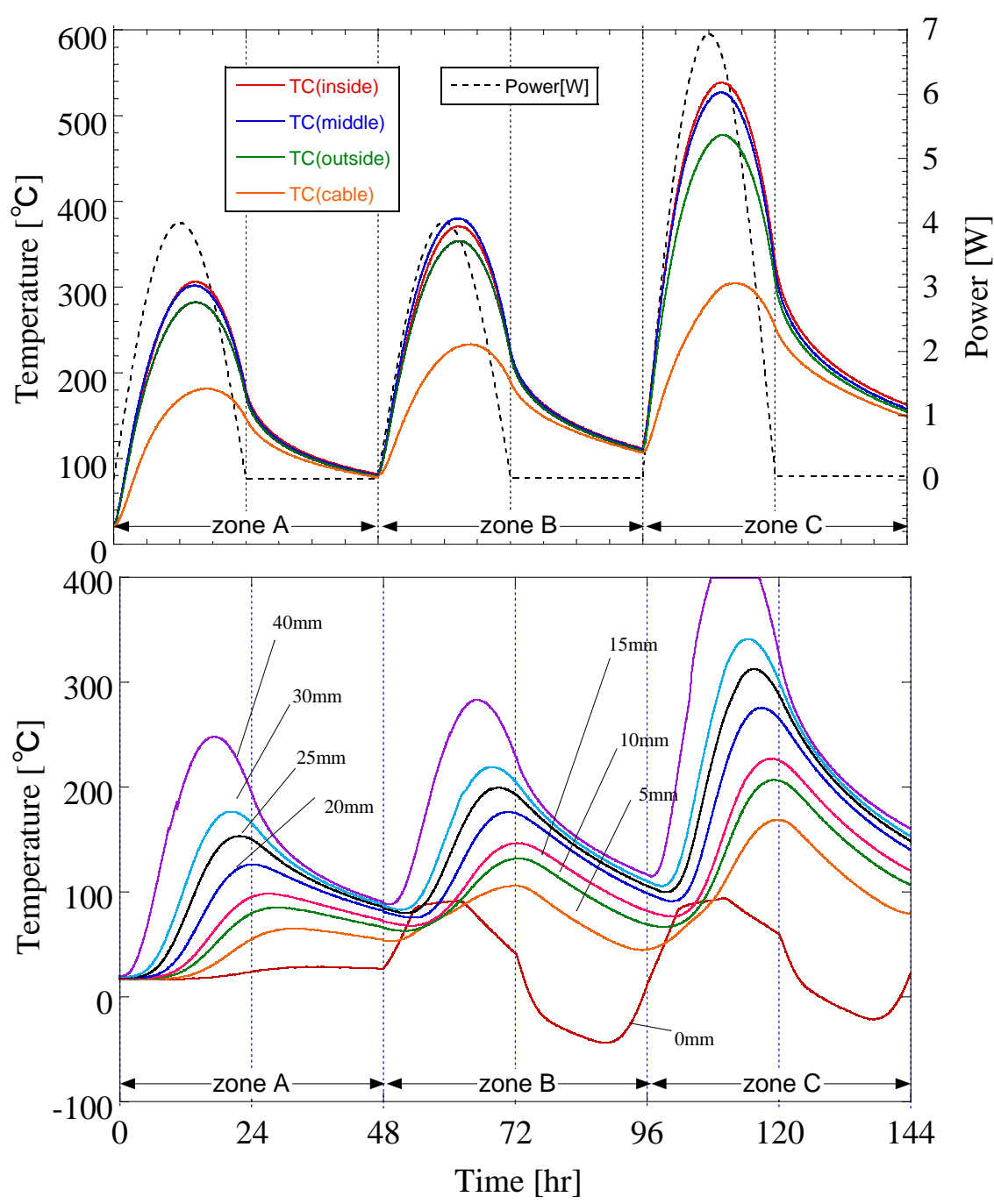

Fig. 11 Temperature Histories of Each Depth $\quad$ (a) Heater section, (b) In regolith simulant

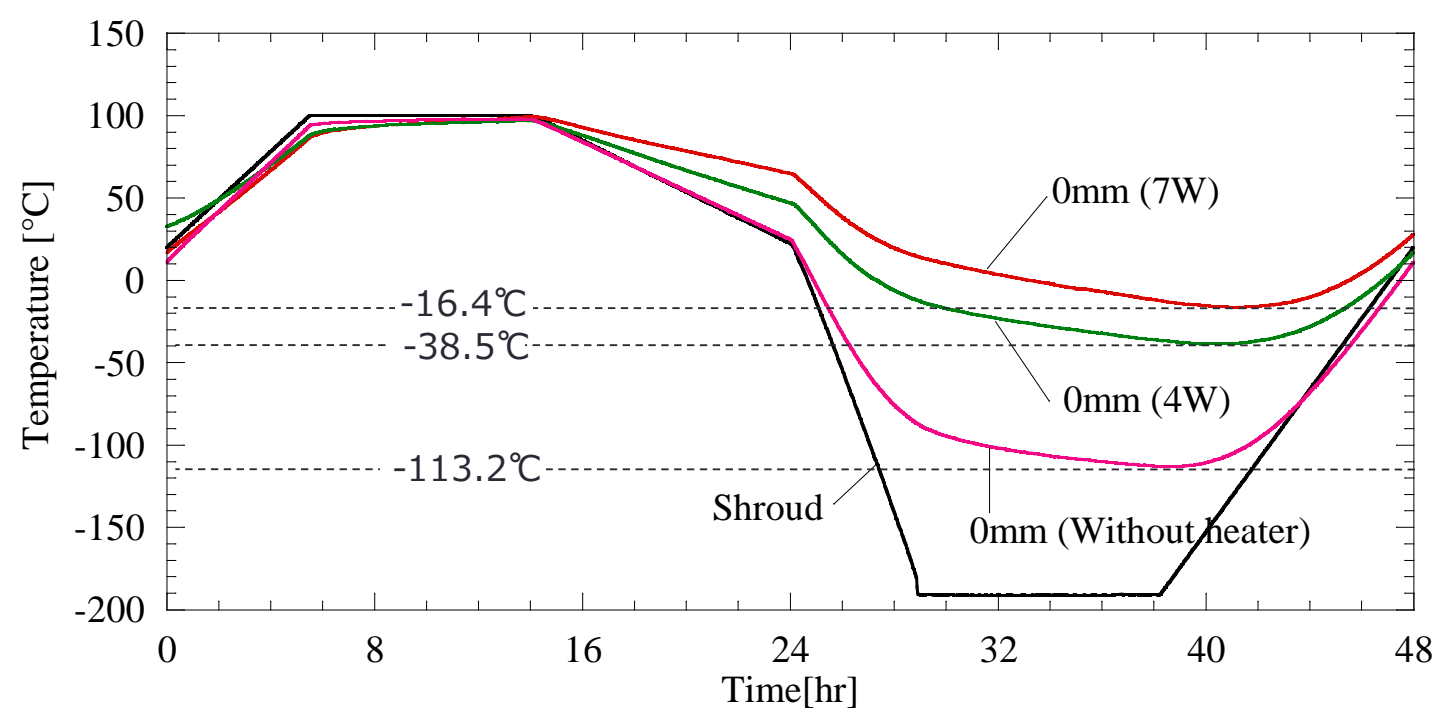

Fig. 12 Comparison of Surface Temperatures 


\section{6. 結論}

月面長期滞在に向けた新しい熱制御手法として，レゴリスとヒータを組み合わせた受動的熱制御方法を提 案した。 その有効性を検証するため月面環境模擬装置を構築し，熱試験を行った．以下に成果をまとめる.

・ 月表面およびレゴリス層内の熱環境を，時間および空間スケールを縮小して模擬できる装置を新たに 構築した.

・ 実際の月面周期加熱環境を小型月面模擬装置で等価的に模擬するため，月面熱環境条件とレゴリスの 熱物性および実験用レゴリスシミュラントの熱物性および実験装置スケールの関係から, 周期加熱条件お よびヒータ設置深さを決定した.

・ 構築した小型月面模擬装置と決定された周期加熱条件を用いて，本提案の受動型熱制御手法の妥当性 の検証を行った. その結果，月面環境と同様にレゴリスシミュラント内の所望の位置に温度一定環境を作 ることができた．また，昼間にヒータ加熱によりレゴリスの所望の深さを加熱することで，夜間の低温ピ ーク時にレゴリスシミュラント層の温度を上昇できることが実証された.

今後は実際の月面熱環境の詳細熱解析モデルを構築し，探査機が受動的に熱制御できる条件を解析的に明 らかにする．また小型月面模擬装置内に探査機を模擬した供試体を設置して熱真空試験を行い，計算と実験 双方から本提案の有効性を示し，ヒータ電力削減量を定量的に明らかにすることを予定している.

\section{謝 辞}

本研究費の一部は科学研究費補助金（20560741）を用いた。また，本月面環境模擬装置の構築においては 宇宙航空研究開発機構の星野健氏のご支援ならびにアドバイスをいただいた。記して謝意を表す.

\section{References}

Balasubramaniam, R., Gokoglu, S., Sacksteder, K., Wegeng, R. and Suzuki, N., Analysis of solar-heated thermal wadis to support extended-duration lunar exploration (2010), NASA/TM-2010-216254.

Heiken, G. H., Vaniman, D. T. and French, B. M., Lunar Sourcebook, A user's guide to the moon (1991), Cambridge University Press.

Kokhanov, A., Karachevtseva, I., Oberst, J., Zubarev, A. and Robinson, M. S., Cartography and information systems for the luna-glob landing sites, European Planetary Science Congress 2012 (2012), EPSC2012-467.

Langseth, M. G. Jr., Keihm, S. J. and Chute, J. L Jr., Heat flow experiment, Apollo 17, Preliminary Science Report (1973), NASA SP-330.

Nagano, H., Ohnishi, A. and Nagasaka, Y., Development of a lightweight deployable/stowable radiator for interplanetary exploration, Applied Thermal Engineering, Vol. 31, No. 16 (2011), pp. 3322-3331.

Notsu, R., Nagano, H. and Ogawa, H., A proposal of lunar long-duration method by using high heat storage capability of regolith, Proceedings of the 43rd International Conference on Environmental Systems (2013), AIAA 2013-3350.

Tanaka, S., Mitani, T., Otake, H., Ogawa, K., Kobayashi, N., Hashimoto, T., Hoshino, T., Otsuki, M., Wakabayashi, S., Kimura, J. and Kuramoto, K., Present status of the lunar lander project SELENE-2, Proceedings of the 44th Lunar and Planetary Science Conference, LPI Contributions No. 1719 (2013), p. 1838.

Tarnawski, V. R., Momose, T., Leong, W. H., Bovesecchi, G. and Coppa, P., Thermal conductivity of standard sands. Part I. dry-state conditions, International Journal of Thermophysics, Vol. 30, No. 3 (2009), pp. 949-968.

Ulamec, S., Jens, B. and Trollope, E., How to survive a lunar night, Planetary and Space Science, Vol. 58, No. 14 (2010), pp. 1985-1995.

ZeZhou, S., Jia, Y. and Zang, H., Technological advancements and promotion roles of Chang'e-3 lunar probe mission, Science China Technological Sciences, Vol. 56, No. 11 (2013), pp. 2702-2708. 